\title{
The Impact of Corruption on FDI in Some MENA Countries
}

\author{
Atef Saad Alshehry
}

\author{
College of Administrative Sciences, \\ Najran University, Saudi Arabia. \\ Email:shehphone@gmail.com \\ Tel: 00966583120015 \\ Licensed: \\ This work is licensed under a Creative \\ Commons Attribution 4.0 License. \\ Keywords: \\ Corruption \\ FDI \\ Economic growth \\ Corruption perception index \\ Panel data model \\ MENA countries. \\ JEL Classification \\ E22; OOO. \\ Received: 11 May 2020 \\ Revised: 23 June 2020 \\ Accepted: 25 June 2020 \\ Published: 13 July 2020
}

\begin{abstract}
Foreign direct investment plays a major role in the economic growth of developing countries. It is one of the most important sources of foreign financing for development in these countries. The developing countries suffer from a shortage of domestic resources, as foreign investment has advantages that make it superior to loans. Since economic growth cannot be achieved without investment; and investment without an attractive and distinctive climate, and in this context, economic policies in MENA have witnessed a great interest in FDI flows. This has necessitated the need to identify the impediments to FDI inflows that may be one of these impediments to the development process is corruption. This paper studies the effect of corruption on foreign direct investment inflows for 14 MENA countries during the period of 2003 to 2016 by employing a panel data fixed effects model. The findings indicate the existence of three significant variables that affect FDI inflows. These variables are corruption perception index, political stability index, and trade openness. Results confirm the grabbing hand for FDI inflows hypothesis. The mitigation of corruption at all levels in MENA countries could encourage FDI inflows.
\end{abstract}

Funding: This study received no specific financial support

Competing Interests: The author declares that there are no conflicts of interests regarding the publication of this paper.

\section{Introduction}

Corruption is a universal phenomenon at the intersection of law, economics and politics. In fact, for several centuries, philosophers led reflections on corruption. The political sciences crossed the step of the "demoralization" of the subject by agreeing to study corruption according to an individualistic, utilitarian and functional reading grid. These analyses have the merit of trying to balance the positive and negative effects of the phenomenon on the modernization of countries. The interest of economists in the subject is even more recent since it dates only from the seventies. Economic literature on corruption has been dominated by microeconomic studies (Johnston, 2000). Because of the sensitivity and intrinsically secretive nature of the subject, these studies were limited to descriptive and theoretical aspects of corruption.

In recent years, there has been a renewed interest in corruption among academics and public authorities. This has also increased the concern of bilateral and multilateral aid agencies about the effects of corruption on economic activities and investments. The recent increase in the number of countries interested by controlling corruption have created an environment in which discussions on corruption are no longer a taboo. International financial institutions and non-governmental organizations have contributed to a greater awareness of the economic costs of corruption. High confidence in the market mechanism and the need for competitiveness have given rise to an environment where the search for efficiency requires great importance and distortions attributed to corruption attract more of attention.

Corruption can be administrative corruption, political corruption, economic corruption and financial corruption. It takes many forms such as bribery, nepotism and extortion, etc. Corruption in all its forms and types has negative effects on economic activities in general and in particular on investment, whether domestic or foreign. The growth of foreign direct investment, in many countries and especially in economies in transition, have created many situations in which bribe payments are lucrative for companies that allow them to win profitable contracts. Most of the bribes were paid for foreign contracts or for preferential access to markets or special benefits such as the tax advantage. Another striking feature of the global economy in recent 
decades is the growth of foreign direct investment. FDI is central to any development strategy. Indeed, FDI is a privileged instrument to stimulate and ensure better integration in the increasingly globalized international economic space and a determining factor in the acquisition of technologies and improved competitiveness. This is why the importance of FDI has been steadily increasing, particularly in connection with the opening up of the economies of emerging countries to the external environment and the dismantling of economic frontiers, which has only exacerbated more competition.

In this regard, a host country, characterized by institutional deficiencies and inadequacies relating to the right to property, relations with administrations and the judicial system, is not a preferred destination for foreign investors. The dysfunction of public institutions discourages foreign investors and will have a negative impact on their projects. Corruption is among the symptoms of dysfunction constituting an obstacle to foreign investment. Hence the idea of studying the impact of corruption on foreign direct investment for some Middle East and North Africa (MENA) countries. Most economists often consider corruption as a threat to foreign investment for many reasons. It distorts the economic and financial environment, it reduces the efficiency of government and business by allowing people to gain positions of strength through patronage rather than merit, and it introduces an element of internal instability into the political process. Foreign investors may have difficulty effectively undertaking projects in countries where corruption is widespread. This takes the form of special payment bribes linked with import or export licenses and the estimation of tax charges.

The aim of this paper is to study the effects of corruption in 14 MENA countries over the period 2003 to 2016 using a static panel data model. It will be organized as follows. Section 2 gives an overview of the different definitions and measures of corruption. Section 3 presents a brief literature review on the effects of corruption on FDI. In section 4, I present the model, the various variables used and data sources. In section 5, I present and discuss the empirical results. Finally, I report the conclusions.

\section{Definitions and Measures of Corruption}

Aristotle defined corruption as a form of government that rules in order to satisfy the private interest. He considered corruption as one of phases of growth (Chamseddine, 2016). Corruption seems rebellious to a strict definition and apparently, the authors they use do not always start from the same point of view. Corruption was defined as a philosophical and political concept and had a much broader meaning than it does today. In the past, the definition of corruption gives more importance to the moral dimension in its use. It is the perversion or destruction of integrity in the performance of one's duty through bribes and favours. This rather general classical definition may not apply today because of the complexity of government institutions and the differentiation of social groups and their programs. Hence, there is no longer any reason to judge the corruption of an entire political order. Indeed, for most analysts today, corruption refers to the very specific acts of specific individuals, those who occupy the public service and those who seek to influence them (according to certain definitions). These definitions can be classified according to the classification of behaviours and the principal agent-client relationship (Johnston, 2000).

Behavioural definitions generally equate corruption with the abuse of a public power or resource to gain a private advantage. They identify patterns of corruption, consider institutional and political reforms, and analyse the consequences of various acts of corruption.

Another approach is somewhat different from the previous one, although it is still linked to the behaviour of the public agent. The novelty is that it is based on the analysis of interactions rather than on the definition of a class of actions that are inherently corrupt; it consists of using the "principal-agent-client" manager. A "principal" is an individual or institution that is in charge of performing a function, an "agent" is an individual or institution that actually performs the agency's operation and finally a "client" is a simple individual or institution with which the agent reacts reciprocally. Instead of considering officers or officials isolated, this approach brings the functioning of public bodies back to the relations between a chief of department, for example, with a public service, its agent, who performs operational duties in the jurisdiction in question, and the client, that is, the individual with whom the agent is in contact (Alam, 2009; Johnston, 2000). Accordingly, corruption is defined as "the misuse of public office for private gain", (Chamseddine, 2016).

As previously, reported definitions based on a classification of behaviour are too rigid to apply to all epochs and to all places and their adoption to real societies and in particular to societies in transition poses problems. To remedy this problem, it is necessary to have definitions that should identify a particular type of political problem. This problem is not due to specific acts but rather to broader processes through which influences and authority must be exercised. This approach could be described as "neoclassical" because it seeks to reconcile the modern notions of political corruption with conventional concerns about the moral health of entire societies. This approach by integrating the political dimension of corruption does not discuss specific categories of behaviour, but reveals the interaction between official institutions and social practices, which together constitute the public order system of a society that exalts the common interest against the personal interest (Farrales, 2005; Thompson, 1993).

Finally, according to Senior (2006) corruption exists when the following five conditions occur simultaneously: "when a corruptor (1) covertly gives (2) a favour to a corrupted or to a nominee to influence (3) action(s) that (4) benefit the corruptor or a nominee, and for which the corrupted has (5) authority." 
Now days, all the International Institutions recognize corruption as an epidemic for economic development. It is a barrier to an equitable development. For example, the World Bank considers corruption as a social and economic issue that should be debated at the national and international levels. Transparency International launched in 1995 the corruption perception index to measure corruption. This index is annually and it permits the ranking of countries according to their levels of corruption. A good ranking could attract foreign investors. Later in 2003, the United Nations lunched the United Nations Convention to combat corruption (Chamseddine, 2016).

As the definition of corruption is controversial, its measure represents also an issue. The literature considers three ways to measure corruption. Firstly, it can be measured by the audits of specific projects. Secondly, the institutional features of a country can approximate it. Thirdly, corruption is measured by questioning the firms, the public officials, observers in NGOs, multilateral donors, and individuals (Chamseddine, 2016). Transparency International adopts this type of measure for corruption that is called corruption perception index.

Since the 1990s, there has been an explosion of interest in the construction of indices and indicators of corruption and governance. Arndt and Oman (2006) reported the existence of more than one hundred governance indicators. These indicators and indices have been subject to different methodological changes. The most important indicators are : the Corruption Perceptions Index (CPI), the Bribery Perception Index (BPI) performed by TI; the Business Environment and Enterprise Performance Survey performed by the European Bank for Reconstruction and Development and the World Bank; the Corruption Experience Index and the Business International Index issued by Business International; the World Bank Governance Indicators Database (WGI); the International Country Risk Guide (ICRG); the Global Competitiveness Report (GRC); the World Competitiveness Yearbook; and the Global Competitiveness Report (GRC) (for more details, see Malito (2014).

\section{A Literature Review}

Corruption is a source of uncertainty and rising costs for businesses. Michalet (1997) sought to answer the question to what extent the transition of Central and Eastern European countries to market economies has allowed FDI to be diverted from Mediterranean and sub-Saharan African countries. Its study is based on a survey of 90 multinationals in Western Europe, North America and Japan, supplemented by studies of the investment environment in a sample of countries from different regions. Among the conclusions reached by the author is a recommendation for countries seeking to attract foreign direct investment. A precondition for encouraging investment is a stable political and economic climate and a transparent and non-discretionary legal and regulatory framework. Without these characteristics, a country is excluded from the Centre, that is, it is not the destination of FDI. However, minimizing the costs associated with doing business and establishing a predictable business environment is a necessary but not sufficient condition. The host country should be able to change its position from the long list to the short list of relocation preferences. Therefore, the chances of success of the investment promotion policy will depend on its ability to move a country from the circle of potential candidates to the circle of central countries. The author concluded that market-related economic determinants are necessary for the selection of the host country, but they are not sufficient in themselves. In their responses, the firms interviewed noted a series of other factors that determine their final decision to invest in a country that meets the basic conditions. These factors also determine whether the country could be among the central countries or whether it remains on the list of countries with potential attraction. Among these factors, firms state that the legal and regulatory framework governing private affairs should be stable, transparent and reliable. That requires a number of elements. First, the rules of the game must be stable. A few interviewees said that they are more comfortable when dealing with a country where the government imposes ex ante constraints than with a country that initially is permissive but then changes the rules of the game. Second, the legal system should be able to enforce laws and contracts honestly and effectively. Third, once the decision of investment is taken and the subsidiary is installed, the success of the investor in keeping business costs to a minimum would depend on the possibility of having a climate without the parasitic costs generated by bureaucracy and corruption.

Anupam and Srinivasan (2002) analysed the experiences of some sub-Saharan African countries that have been successful in attracting FDI. They found that a transparent institutional environment is very important in the decision to relocate. They found, for example, that in Botswana the level of corruption is important for FDI. Among the most important determinants of FDI is good governance and low levels of corruption.

The impact of corruption on FDI is controversial. Firstly, some authors found it as grabbing hand for FDI (e.g. (Al-Sadig, 2009; Egger. \& Winner, 2006; Habib \& Zurawicki, 2002; Wei, 1999)). According to Wei (1999) corruption acts as an arbitrary tax. The random nature of corruption creates additional burdens because the search cost of those for whom bribes should be added to the costs of negotiation and payment. In addition, the obligations obtained by the payment of bribes could be violated if corruption is decentralized. Empirically, Wei (1999) through cross-sectional data of bilateral FDI, showed that the increase in the level of corruption in the host country negatively affects the inflow of FDI flows. The author found that there was clear evidence that corruption in host countries discouraged foreign investment. For example, if India wants to 
reduce its level of corruption from 5.75 to the estimated level of corruption in Singapore, the effect of this on attracting foreign investments will be equal to a $22 \%$ reduction in the tax rate on companies. Many Asian countries offered tax incentives to lure transnationals. For example, China provided international enterprises with two-year tax exemption in addition to three consecutive years at half tax rate. If this measure comes to reduce domestic corruption and encourage foreign investment, it indicates a high level of corruption in China. If this measure comes to alleviate the fact that Asian countries can attract foreign investment without tax incentives if they can control domestic corruption in their countries. Hines (1995) found the same result. He indicated that corruption discourages foreign investors and it is an obstacle to investment. Furthermore, according to Egger and Winner (2005) corruption grants multinational firms transaction costs through the payment of bribes and the waste of resources. This effect highlights the decline in investment in countries where corruption prevails. Both authors indicated that corruption exerts a form of pressure on foreign investors, which negatively affects their incentive to invest. Similarly, Habib and Zurawicki (2002) found a negative relationship between corruption and FDI for the case of 89 developed and developing countries. By employing a panel data model, Egger. and Winner (2006) found that corruption has a negative impact on FDI inflows in a set of 59 developed and less developed countries. Al-Sadig (2009) found that corruption has an adverse effect on incoming FDI. A $1 \%$ increase in the corruption level could reduce FDI inflows by about $11 \%$.

Studying the effects of corruption on FDI inflows in 16 Asian countries over the period 1995-2009, Alemu (2012) found that a $1 \%$ decrease in the level of corruption could lead to a $9 \%$ increase in FDI inflows. By analysing the effect of corruption on FDI inflows for 33 developing countries over the period 1985 to 2011 , Azam and Ahmad (2013) found that the significant factors influencing FDI inflows in 33 developing countries are corruption index, market size and inflation rate. They found that corruption affects negatively FDI inflows. Not later (Castro, 2013) analysed the effects of corruption on FDI inflows for 73 countries over the period 1998-2008. Their findings indicated that FDI inflows are greater in countries with less corruption. Quazi (2014) studied the effects of corruption on FDI inflows in nine East Asia countries and seven South Asia countries using panel data model over the period 1995 to 2011. Their findings confirm the "grabbing hand" hypothesis for both regions. Ayadi, Ajibolade, Williams, and Hyman (2014) found a long-run relationship between the level of transparency and FDI inflows into 13 Sub-Saharan Africa for the period of 1998 to 2008.

Secondly, other authors showed that corruption could be a helping hand for FDI (e.g. (Bardhan, 1997; Cuervo-Cazurra, 2006; Quazi., Vemuri, \& Soliman, 2014)). Corruption can be beneficial around administrative and regulatory restrictions. In fact, multinational companies agree to pay bribes in order to speed up the bureaucratic process and obtain legal permissions to launch their projects in a short time, hence the application of speed money. Bardhan (1997) reported that bribes save wait times as they act as an accelerator within the administration. In addition, corruption is considered as helping hand because it deflects government-imposed rigidities that prevent investment and hinder other economic decisions that favour economic growth (Belloumi \& Alshehry, 2018). In addition, economic growth could affect income inequality and poverty (Khemili \& Belloumi, 2018). Corruption in host countries can have a positive impact on the attractiveness of foreign investment. Moreover, the Grease payment argument is reinforced by the experience of East Asia. Some admit that this region is unique as it is a popular destination for foreign investors despite high rates of corruption. Egger and Winner (2005) argued that corruption could be a stimulus for FDI. Using panel data for 73 developed and developing countries over the period 1995-1999, they showed that in the short-term corruption could have a positive impact on FDI inflows. Since corruption has binding bureaucratic rules, foreign investors can take advantage of the dishonest processes used by employees to circumvent regulations. Cuervo-Cazurra (2006) showed that foreign investors from corrupt home countries tend to invest in host corrupt countries. Quazi. et al. (2014) studied the impact of corruption on FDI inflows in 53 African countries over the period 1995-2012 using a dynamic panel data model. Their findings indicated that corruption facilitates the incoming of FDI in Africa.

\section{Methodology}

The host country's strategy for attracting FDI depends on the existence of some factors, which essentially concerns political stability, legal environment, corruption level, market size, trade openness, and inflation rate. The impact of corruption on FDI inflows in MENA countries is investigated by estimating the following panel data model initially developed by Mauro (1995) and Abed and Davoodi (2000):

$\mathrm{FDI}_{\mathrm{it}}=\beta_{0}+\alpha_{\mathrm{i}}+\beta_{1} \mathrm{GDP}_{\mathrm{it}}+\beta_{2} \mathrm{INF}_{\mathrm{it}}+\beta_{3} \mathrm{TO}_{\mathrm{it}}+\beta_{4} \mathrm{PSI}_{\mathrm{it}}+\beta_{5} \mathrm{RQI}_{\mathrm{it}}+\beta_{6} \mathrm{CPI}_{\mathrm{it}}+\varepsilon_{\mathrm{it}}$

Where i represents 14 MENA countries $(i=1,2, \ldots, 14)$ and $t$ represents the years $(t=2003,2004, \ldots$, 2016) ${ }^{1}$. The coefficients $\beta_{0}, \beta_{\mathrm{k}}$ and $\alpha_{\mathrm{i}}$ represent the constant, the effects of independent variables, and the country specific effects. The random errors are represented by $\varepsilon_{i t}$.

The dependent variable FDI is represented by foreign direct investment inflows as percentage of GDP. Dividing FDI inflows by GDP for each country permits to adjust the level of investment to the size of the economy. The different independent variables are the logarithm of gross domestic product per capita (LGDP), inflation rate (INF), trade openness represented by exports plus imports to GDP (TO), political stability index

${ }^{1}$ The countries studied are Algeria, Bahrain, Kuwait, Oman, Saudi Arabia, Iran, Tunisia, Morocco, Mauritania, Jordan, Egypt, Iraq, Qatar, and Sudan. 
(PSI), Regulatory quality index (RQI), and corruption perception index (CPI). The variables PSI and RQI take the values from -2.5 (weak) to 2.5 (strong). The CPI is the proxy of the level of corruption. It takes the values $\mathrm{O}$ (strong corruption) to 100 (no corruption). It is available on the Internet at the website of Transparency International (TI) (www.transparency.org). TI publishes the CPI annually since 1995. All other data series are taken from the online world development indicators of the World Bank database (World Development Indicators, 2018).

The political stability encompasses the institutions and public policies developed by governments as a framework for economic and social relations. More attention is being paid to elements of political infrastructure that can influence multinational firms' investment decisions. Therefore, political stability would first include an effective, impartial and transparent legal system that protects property and individual rights, then stable, credible and honest public institutions, and finally, government policies that promote free and open markets. These conditions favour FDI and sunk investments by multinationals that support efficient exploitation in the host country. As a result, political stability is essential for foreign investors. In fact, investors do not like uncertainty; and, faced with the problems of political and social instability symbolized by military and civil conflicts, investors prefer to postpone their investment programs, or divest or invest in another third country. Hence, political stability is a determining factor in the location of FDI. Investors prefer to locate subsidiaries in a country where there is less uncertainty, as political stability has a positive effect on foreign direct investment inflows (Schneider \& Frey, 1985).

In order for investors to be encouraged to locate abroad, host countries must guarantee legal and legal stability to multinational firms. In fact, the legal framework is legal including the regulations governing FDI, its activities, the standards of treatment of foreign subsidiaries and the rules of operation of the markets. In order to attract FDI, the host country is encouraged to ensure the minimization of litigation costs; guarantee the protection of property rights to foreign investors and enjoy the same rights as local investors; ensure the possibility of repatriation of profits and capital in the event of liquidation; establish a free exchange market; and establish investment incentive programs based on transparent modulation of many tax and customs advantages. Thus, legislation is important to attract FDI, and therefore complex or confusing legislation would not encourage foreign investors.

Market size is an important determinant of FDI inflows. It is determined by the level of real gross domestic product per capita (constant 2010 US dollars). Indeed, large markets in which consumer demand is far from being met represent a potential that attracts foreign investors (Lim, 2001). The level of GDP is also a proxy for economic growth.

It is common for open economies to encourage foreign investment. In fact, the opening of a country to trade is expressed by the progressive reduction of controls and restrictions that oppose free trade. Many authors tested the impact of trade openness on FDI inflows and they found it to be an important determinant (Levy-Yeyati, Stein, \& Daude, 2003; Lim, 2001).

The descriptive statistics of the different variables are shown in Table 1.

Table-1. Descriptive statistics of the different series

\begin{tabular}{c|c|c|c|c|c|c}
\hline Variables & FDI & CPI & GDP & PSI & TO & INF \\
\hline Mean & 3.382 & 38.552 & 14542.98 & -0.594 & 85.596 & 6.569 \\
\hline Median & 2.170 & 37.000 & 4483.070 & -0.525 & 86.755 & 4.050 \\
\hline Maximum & 26.530 & 77.000 & 72670.96 & 1.220 & 159.770 & 53.200 \\
\hline Minimum & -3.110 & 11.000 & 1125.760 & -3.180 & 19.100 & -10.100 \\
\hline Std. Dev. & 4.013 & 14.257 & 18678.62 & 0.997 & 31.122 & 8.046 \\
\hline Skewness & 2.659 & 0.173 & 1.780 & -0.231 & 0.136 & 2.660 \\
\hline Kurtosis & 12.785 & 2.533 & 5.225 & 2.648 & 2.703 & 12.227 \\
\hline
\end{tabular}

\section{Empirical Results}

Before estimating the panel data model given by Equation 1, the Fisher test is used to check the existence of specific effects $\alpha_{i}$. From an economic point of view, the specification test of Fisher permits whether one can assume that the FDI-corruption relationship is perfectly identical for all countries, or on the contrary, if there are country-specific characteristics. The p-value associated to this test is equal to zero indicating that we reject that all the specific effects are equal to zero. Hence, there exists a panel data model with specific individual effects. As the number of cross sections exceeds the number of estimated coefficients, both random effects model and fixed effects model could be implemented. The results of Hausman (1978) indicate that the specific effects are fixed effects and not random. In fact, the p-value of Hausman test is equal to $4 \%$, indicating that the null hypothesis is rejected at $5 \%$ level of significance. This result indicates that the model can be specified as a panel with individual effects. These individual effects represent the heterogeneous effects. The fixed effects model is advantageous in that it assumes that the coefficients are different for all countries. The average effects of non-explanatory variables can explain the origin of the heterogeneity of FDI inflows. This heterogeneity is due, for example, to the economic characteristics of each country, and the degree of openness of the economy in each country in this sample. 
The specification tests show that the theoretical model can be formalized as a panel with individual effects. Hence, the individual effect model is estimated using the within method.

In order to estimate this relationship for these countries we will use within and GLS (MCG) techniques. Table 2 reports the results of the within method and Hausman test. The results of estimation indicate significance of three variables that are corruption perception index, political satiability index and trade openness. The coefficient of CPI is positive and significant at a level of $10 \%$. This indicates that a high level of the index of corruption has a positive effect on FDI inflows. It means that a country with a low level of corruption could encourage the FDI inflows. In addition, the coefficient of PSI is positive and significant at $5 \%$. This indicates that political stability is determinant for FDI inflows in MENA region where many countries suffer from that. The variable TO has a positive coefficient and it is significant at only $1 \%$. This shows that a high degree of openness of an economy encourages the FDI inflows.

Table-2. Results of estimation.

\begin{tabular}{l|c|c|c|c}
\hline Variable & Coefficient & Std. Error & t-Statistic & Prob. \\
\hline LGDP & 0.949 & 2.412 & 0.393 & 0.694 \\
\hline INF & -0.009 & 0.036 & -0.267 & 0.789 \\
\hline CPI & 0.096 & 0.052 & 1.852 & 0.065 \\
\hline PSI & 1.537 & 0.720 & 2.133 & 0.034 \\
\hline TO & 0.126 & 0.020 & 6.021 & 0.000 \\
\hline C & -18.598 & 21.866 & -0.850 & 0.396 \\
\hline R-squared & \multicolumn{5}{|c}{0.522} \\
\hline Adjusted R-squared & 0.472 \\
\hline F-statistic & 10.397 \\
\hline Prob (F-statistic) & 0.000 \\
\hline Hausman Test & \multicolumn{5}{|c}{0.042} \\
\hline Chi-Sq. Statistic & \multicolumn{5}{|c}{1.493} \\
\hline Prob. & \multicolumn{5}{|c}{} \\
\hline
\end{tabular}

\section{Conclusion}

This paper investigates the impact of corruption on foreign direct investment inflows in 14 MENA countries. In theory, this impact is the subject of a debate: it could be negative (grabbing hand) or positive (helping hand). The results of this study validates the grabbing hand hypothesis. All countries in the world are now seeking to attract more investment because of its positive impact on the economy. It is the source of new technologies and new management and marketing procedures. The attractiveness of FDI inflows by a country is determined also by political stability and trade openness. Transparent economic policies positively influence investor behaviour. The dysfunction of public institutions will have a negative impact on foreign direct investment. The phenomenon of corruption presents an example of symptoms of markets dysfunction. Indeed, systems characterized by non-transparency and high levels of corruption are not favorable climates for investors. Generally, barriers, such as licensing to invest, put in place by governments, limit the entry and activity of foreign players in markets. The bureaucracy has the task of controlling restrictions and regulations, from which arise easy opportunities for corruption.

In order to reduce corruption levels and hence encourage the incoming of FDI, MENA countries should reform their judicial systems to ensure integrity, independence and capacity building; reform civil service and other institutional reforms to improve the flow of information, increase the incentives for honesty and good performance; and simplify the tax regimes and regulations.

\section{References}

Abed, G., \& Davoodi, H. (2000). Corruption, structural reforms, and economic performance in the transition economies. IMF Working paper WP/oo/132.

Al-Sadig, A. (2009). The effects of corruption on FDI inflows. Cato Journal, 29(2), 267-294.

Alam, M. S. (2009). Anatomy of corruption: An approach to the political economy of underdevelopment. American Journal of Economics and Sociology, 48(4), 441-456.

Alemu, A. M. (2012). Effects of corruption on FDI inflow in Asian economies. Seoul Journal of Economics, 25(4), 387-412.

Anupam, B., \& Srinivasan, K. (2002). Foreign direct investment in Africa: Some case studies. IMF Working Paper $\mathrm{N}^{\circ} 02 / 61$.

Arndt, C., \& Oman, C. P. (2006). Uses and abuses of governance indicators (pp. 126). Paris. France: OECD Publications.

Ayadi, F. O., Ajibolade, S., Williams, J., \& Hyman, L. (2014). Transparency and foreign direct investment into Sub-Saharan Africa. African Journal of Economic and Management Studies, 5(2), 146-159.

Azam, M., \& Ahmad, S. A. (2013). The effects of corruption on foreign direct investment inflows: Some empirical evidence from less developed countries. Journal of Applied Sciences Research, 9(6), 3462-3467.

Bardhan, P. (1997). Corruption and development: a review of issues. Journal of Economic Literature, 35(3), 1320-1346. 
Belloumi, M., \& Alshehry, A. (2018). The impacts of domestic and foreign direct investments on economic growth in Saudi Arabia. Economies, 6(1), 18-34.

Castro, C. (2013). Does corruption inhibit foreign direct investment? Politics. Political Science Magazine, 51(1), 6183.Available at: https://doi.org/10.5354/0716-1077.2013.27418.

Chamseddine, N. (2016). Corruption and economic growth in the middle East and North Africa. Senior Theses, Trinity College, Hartford, CT.

Cuervo-Cazurra, A. (2006). Who cares about corruption? Journal of International Business Studies, 37(6), 807-822.Available at: https://doi.org/10.1057/palgrave.jibs.8400223.

Egger, P., \& Winner, H. (2005). Evidence on corruption as an incentive for foreign direct investment. European Journal of Political Economy, 21(4), 932-952.Available at: https://doi.org/10.1016/j.ejpoleco.2005.01.002.

Egger., P., \& Winner, H. (2006). How corruption influences foreign direct investment: A panel data study. Economic Development and Cultural Change, 54(2), 459-486.Available at: https://doi.org/10.1086/497010.

Farrales, M. J. (2005). What is corruption? a history of corruption studies and the great definitions debate. Retrieved from: https://ssrn.com/abstract $=1739962$.

Habib, M., \& Zurawicki, L. (2002). Corruption and foreign direct investment. Journal of International Business Studies, 33(2), 291-307.

Hausman, J. A. (1978). Specification tests in econometrics. Econometrica, 46(6), 1251-1271.

Hines, J. J. (1995). Forbidden payment: Foreign bribery and American business after 1977. NBER Working Paper No 5266.

Johnston, M. (2000). The new corruption rankings: Implications for analysis and reform. Quebec City: International Political Science Association.

Khemili, H., \& Belloumi, M. (2018). Cointegration relationship between growth, inequality and poverty in Tunisia. International Journal of Applied Economics, Finance and Accounting, 2(1), 8-18.Available at: https://doi.org/10.33094/8.2017.2018.21.8.18.

Levy-Yeyati, E. L., Stein, E. H., \& Daude, C. (2003). Regional integration and the location of FDI. IDB Working Paper No. 414.

Lim, E.-G. (2001). Determinants of, and the relation between, Foreign direct investment and growth: A summary of the recent literature. Washington D.C.: Working Paper 01/175, International Monetary Fund.

Malito, D. V. (2014). Measuring corruption indicators and indices. European University Institute (EUI) Working Paper, the Robert Schuman Centre for Advanced Studies (RSCAS) 2014/13.

Mauro, P. (1995). Corruption and growth. The Quarterly Journal of Economics, 110(3), 681-712.

Michalet, C. A. (1997). Strategies of multinational and competition for foreign direct investment: The opening of central and Eastern Europe. Foreign Investment, Advisory Service, Occasional Paper $\mathrm{N}^{\circ} 10$, World Bank

Quazi, R. M. (2014). Corruption and foreign direct investment in East Asia and South Asia: An econometric study. International Journal of Economics and Financial Issues, 4(2), 231-242.

Quazi., R., Vemuri, V., \& Soliman, M. (2014). Impact of corruption on foreign direct investment in Africa. International Business Research, 7(4), 1-10.

Schneider, F., \& Frey, B. S. (1985). Economic and political determinants of foreign direct investment. World Development, 13(2), 161-175.

Senior, I. (2006). Corruption - the world's big C: Cases, causes, consequences, cures (pp. 207). London, UK: The Institute of Economic Affairs

Thompson, D. F. (1993). Mediated corruption: The case of the Keating five. American Political Science Revierw, 87(2), 369381.Available at: https://doi.org/10.2307/2939047.

Wei, S.-J. (1999). Corruption in economic development: Beneficial grease, minor annoyance, or major obstacle? World Bank Policy Research Working Paper No. 2048.

World Development Indicators. (2018). World bank. Washington, DC, USA. Retrieved from http://databank.worldbank.org/data/download/WDI_excel.zip. 